\title{
Polyol mixture supplementation as a sweetener and/or feed additive in the diet of piglets
}

\author{
MATTI NÄSI ${ }^{1}$ and TIMO ALAVIUHKOLA ${ }^{2}$ \\ 1 Department of Animal Husbandry, University of Helsinki, 00710 Helsinki 71 \\ 2 Swine Research Station, os 840 Hyvinkää 4
}

\begin{abstract}
In a $2 \times 2$ factorial experiment the use of polyol mixture (sugar alcohols) in the diet of piglets was investigated by comparing it to sucrose as a sweetener or to growth promoter olaquindox. In the experiment 80 litters, eight or more piglets per litter, were allotted four dietary treatments: sucrose $4 \%$ (1), sucrose $4 \%+$ olaquindox $50 \mathrm{mg} / \mathrm{kg}$ feed (2), polyol $8 \%, 4 \% \mathrm{DM}$ (3) and polyol $8 \%$ + olaquindox $50 \mathrm{mg} / \mathrm{kg}$ feed (4). Creep feed was offered from one week's age. The post weaning feeding period was from 5 to 7 weeks' age. The litter size was 9.9 piglets on average. The mortality of piglets was $11.2 \%, 8.4 \%, 8.8 \%$ and $6.4 \%$ in groups 1 , 2,3 and 4 during the experimental period $7-49 \mathrm{~d}$. After weaning the groups receiving growth promoter grew significantly $(\mathrm{P}<0.01)$ better, $13.8 \%$ and $24.0 \%$ compared to the controls. Polyol and sucrose groups were equal. Feed consumption before weaning was small, $31 \mathrm{~g} / \mathrm{d}$, on average. After weaning there were no differences between groups in feed consumption. Relative feed conversion efficiences were 100, 79, 90 and 81 for groups $1,2,3$ and 4 . The growth promoter decreased the incidence of diarrhoea in piglets after weaning. By using polyol mixture as a sweetener sucrose could be substituted and the mortality of piglets was reduced. The use of growth promoter improved the performance of piglets.
\end{abstract}

\section{Introduction}

A difficult phase in piglet rearing is the transition period from suckling to the starter phase. The risk of infections, change of feed and the lack of appetite followed by overeating cause severe stress in piglets and their defence reactions leading to losses due to gastrointestinal disorders and mortality.

For successful weaning it is important that starter diets are palatable. Young pigs respond to sweetness and by adding sugars to the diet the feed intake could be increased (LEWIS et al. 1955, ALDINGER et al. 1961). Polyol mixture or sugar alcohols, a by-product of xylitol production from xylane-containing material, is a sweetening substance. Savings could be achieved by replacing sugar with a less expensive form of sweetener such as polyol mixture. Sugar alcohols have been found to have antimicrobial effects (SCHEININ and MÄKINEN 1975, KORHONEN et al. 1977, MÄKINEN et al. 1981) and the purpose of the work was to study the effect of polyols on reducing or preventing diarrhoea.

The study is part of a research project directed at the utilization of sugar alco- 
hols in the nutrition of domestic animals. It is a follow-up examination of the effect of polyol supplementation on piglet performance after a preliminary investigation (NÄSI and ALAVIUHKOLA 1980).

Materials and methods

The study comprised eighty litters of landrace and large white cross sows of the Swine Unit of Porlammi Co-operative Dairy. The piggery is a commercial enterprise of four hundred sows and four thousand growing pigs utilizing by-products from dairy industry in the feeding of pigs. The experiment was conducted in two departments of the unit. Only litters with eight or more piglets aged seven days were taken into the experiment. The litters were divided in four groups, twenty in each, in rotation. All sows had the same feeding regime during the gestation and lactation periods. During the lactation period the sows were fed with a mixture of grain and protein concentrate according to the number of piglets $(2.8 \mathrm{~kg}+0.3 \mathrm{~kg} /$ piglet feed daily).

The litters were taken in the experiment at the age of seven days. Creep feed was offered on the floor from the beginning of the trial. The recording of feed consumption was made from three weeks of age from creep feeders, in which feed was allowed ad libitum. Piglets were weighed at seven days of age and thereafter at the age of three, five and seven weeks. A check for diarrhoea of litters was made daily and for every individual piglet with the weighing. Weaning took place at 5 weeks. Piglets remained in the pens until the experiment was terminated at 7 weeks of age.

The four groups of twenty litters were as follows:

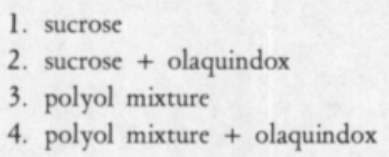

The creep feed for piglets was supplemented with either $4 \%$ of sucrose or $8 \%$ (4\% DM) of polyol mixture. The growth promoter, olaquindox, trade name bayonox ${ }^{\circledR}$, supplementation was $50 \mathrm{mg} / \mathrm{kg}$ feed. All diets were given in a pelleted form.

Feed analyses were made by standard methods (PALOHEIMO 1969) and the sugar alcohol composition of the polyol mixture was analysed with a gas chromatograph (Carlo Erba 180).

The average weight gain of piglets for each group was tested by a two-way variance analysis. The data of the feed consumption of litters was tested by the analysis of covariance. The differences between the treatment means were tested by the Tukey-test (STEEL and TORRIE 1960).

\section{Results and discussion}

The composition of diets is presented in Table 1 and the chemical composition of mixtures in Table 2. The average crude protein content in creep feed was $19.5 \%$. 
Table 1. Composition of the diets.

\begin{tabular}{lccccc}
\hline Ingredients, $\%$ & 1 Sugar & $\begin{array}{c}\text { Creep feed } \\
\text { 2 Sugar }+ \\
\text { Olaquindox }\end{array}$ & 3 Polyol & $\begin{array}{c}\text { 4 Polyol }+ \\
\text { Olaquindox }\end{array}$ & $\begin{array}{c}\text { Lactation } \\
\text { diet }\end{array}$ \\
\hline Skim milk powder & 0.5 & 0.5 & 0.5 & 0.5 & 1.6 \\
Whole milk powder & 3.5 & 3.5 & 3.5 & 3.5 & - \\
Fish meal & 6.0 & 6.0 & 6.0 & 6.0 & 5.4 \\
Meat and bone meal & - & - & - & - & 1.8 \\
Dried grass & - & - & - & - & 1.4 \\
Rape seed meal & 3.0 & 3.0 & 3.0 & 3.0 & - \\
Soybean meal & 14.0 & 14.0 & 14.0 & 14.0 & 3.4 \\
Yeast & 1.0 & 1.0 & 1.0 & 1.0 & 1.1 \\
Oats & 9.5 & 9.5 & 9.5 & 9.5 & 20.0 \\
Barley & 30.0 & 30.0 & 30.0 & 30.0 & 62.0 \\
Oatmeal & 20.0 & 20.0 & 20.0 & 20.0 & - \\
Sucrose & 4.0 & 4.0 & - & - & - \\
Sugar alcohol & - & - & 8.0 & 8.0 & - \\
Water & 4.0 & 4.0 & - & 4.5 & 3.2 \\
Mineral and vitamin & 4.5 & 4.5 & 4.5 & & - \\
Supplements & & & & \\
\hline
\end{tabular}

1 Provided per kg creep feed: $\mathrm{NaCl}_{5} \mathrm{~g}, \mathrm{CaHPO}_{4} 20 \mathrm{~g}, \mathrm{Zn} 100 \mathrm{mg}, \mathrm{Mn} 47 \mathrm{mg}, \mathrm{Fe} 158 \mathrm{mg}, \mathrm{Cu} 123 \mathrm{mg}, \mathrm{Se}$ $0.1 \mathrm{mg}$, vitamin A $10000 \mathrm{IU}$, vitamin D, $1000 \mathrm{IU}$, vitamin E $20 \mathrm{mg}$, pantotenic acid $20 \mathrm{mg}$, niasin 40, vita$\min \mathrm{B}_{2} 5.5 \mathrm{mg}$ and vitamin $\mathrm{B}_{6} 4 \mathrm{mg}$.

2 Olaquindox-supplementation $50 \mathrm{mg} / \mathrm{kg}$.

Table 2. Chemical composition of the diets.

\begin{tabular}{|c|c|c|c|c|c|}
\hline In dry matter & $\begin{array}{c}1 \\
\text { Sugar }\end{array}$ & $\begin{array}{c}\text { Creep feed } \\
2 \\
\text { Sugar }+ \\
\text { Olaquindox }\end{array}$ & $\begin{array}{c}3 \\
\text { Polyol }\end{array}$ & $\begin{array}{c}4 \\
\text { Polyol + } \\
\text { Olaquindox }\end{array}$ & $\begin{array}{c}\text { Lactation } \\
\text { diet }\end{array}$ \\
\hline Dry matter, $\%$ & 84.6 & 84.9 & 84.0 & 84.9 & 87.6 \\
\hline Ash, $\%$ & 6.9 & 6.8 & 7.3 & 7.5 & 6.0 \\
\hline Crude protein, $\%$ & 22.7 & 22.7 & 22.0 & 22.8 & 19.1 \\
\hline True protein, $\%$ & 21.0 & 20.8 & 20.3 & 21.3 & 16.9 \\
\hline Ether extract, $\%$ & 4.5 & 4.6 & 5.0 & 4.6 & 3.5 \\
\hline Crude fibre, $\%$ & 5.0 & 5.1 & 5.1 & 5.5 & 6.2 \\
\hline NFE, $\%$ & 60.9 & 60.8 & 60.6 & 59.6 & 65.2 \\
\hline Calcium g/kg & 10.58 & 10.39 & 10.80 & 11.62 & 9.84 \\
\hline Phosphorus g/kg & 7.67 & 7.64 & 7.49 & 7.36 & 6.84 \\
\hline Magnesium $\mathrm{g} / \mathrm{kg}$ & 1.61 & 1.68 & 1.76 & 1.64 & 1.78 \\
\hline Sodium $\mathrm{g} / \mathrm{kg}$ & 3.85 & 4.33 & 4.61 & 4.34 & 3.28 \\
\hline Potassium $\mathrm{g} / \mathrm{kg}$ & 7.68 & 7.31 & 7.53 & 7.18 & 5.39 \\
\hline Iron $\mathrm{mg} / \mathrm{kg}$ & 436 & 370 & 335 & 359 & 313 \\
\hline Copper mg/kg & 144 & 139 & 155 & 112 & 10 \\
\hline Zinc $\mathrm{mg} / \mathrm{kg}$ & 194 & 191 & 191 & 229 & 150 \\
\hline Manganese $\mathrm{mg} / \mathrm{kg}$ & 103 & 106 & 129 & 108 & 71 \\
\hline
\end{tabular}

The dry matter percentage of the polyol mixture was $51.6 \%$. The polyol mixture used in this study had the following composition, \% in dry matter: arabinitol 16.6, erythritol 3.2, galactitol 2.4, glyserol 2.7, mannitol 11.3, rhamnitol 4.9, sorbitol 14.7, xylitol 27.1, glycose 10.0 and other reducing matter 7.1. 
The mean values of litter performances are given in Table 3. The total number of piglets in the experiment was 794, about two hundred in each group. The average litter size at the beginning of the experiment, at seven days of age, was 9.9 piglets. The percentage of the mortality of piglets was on average in the period of 7-49 days $11.2,8.4,8.8$ and 6.4 for groups $1,2,3$ and 4, respectively. After weaning $4.4,3.1,3.3$ and $0.5 \%$ of the piglets died in groups $1,2,3$ and 4 . The most important factors in piglet losses were chrushing and starvation. The climatic environment in the pig house was not good enought because of the very hard winter during the experimental period. Mortality was less in groups fed with a diet supplemented with growth promoter or polyol mixture.

During the suckling period the daily gain of the piglets was $196 \mathrm{~g}$ on average. Groups 1 and 3 grew better during the first two experimental periods $(\mathrm{P}<0.01)$. These groups had a smaller litter size, 0.4 piglet less. Also the mortality of group 1 was higher. Between 3-5 weeks the daily gain was quite similar in all the groups. After weaning, the groups receiving feed additive olaquindox grew significantly $(\mathrm{P}<0.01)$ better, 13.8 and $24.0 \%$, compared to groups without growth promoter. Between supplements of sucrose or polyol mixture there were no differences in the daily gain. In a previous experiment performed at the swine research station the daily gain improved 7 per cent with piglets fed on diet supplemented with polyol mix-

Table 3. Average daily gain, feed intake and feed efficiency of piglets.

\begin{tabular}{|c|c|c|c|c|c|c|c|c|}
\hline \multirow[t]{2}{*}{ Groups } & \multicolumn{2}{|c|}{ 1. Sucrose } & \multicolumn{2}{|c|}{$\begin{array}{l}\text { 2. Sucroset }+ \\
\text { Olaquindox }\end{array}$} & \multicolumn{2}{|c|}{ 3. Polyol } & \multicolumn{2}{|c|}{$\begin{array}{l}\text { 4. Polyol + } \\
\text { Olaquindox }\end{array}$} \\
\hline & $\mathrm{x}$ & s.d. & $\mathrm{x}$ & s.d. & $\mathrm{x}$ & s.d. & $\mathrm{x}$ & s.d. \\
\hline No of litters & 20 & & 20 & & 20 & & 20 & \\
\hline \multicolumn{9}{|l|}{ No of piglets } \\
\hline $7 d$ & 197 & & 202 & & 193 & & 202 & \\
\hline $21 \mathrm{~d}$ & 188 & & 195 & & 187 & & 195 & \\
\hline $35 \mathrm{~d}$ & 183 & & 191 & & 182 & & 190 & \\
\hline $49 \mathrm{~d}$ & 175 & & 185 & & 176 & & 189 & \\
\hline \multicolumn{9}{|l|}{ Piglets/litter } \\
\hline $7 \mathrm{~d}$ & 9.9 & 1.6 & 10.1 & 1.3 & 9.7 & 1.2 & 10.1 & 1.6 \\
\hline $21 \mathrm{~d}$ & 9.4 & 1.8 & 9.8 & 1.4 & 9.4 & 1.0 & 9.8 & 1.6 \\
\hline $35 \mathrm{~d}$ & 9.2 & 1.8 & 9.6 & 1.4 & 9.1 & 0.9 & 9.5 & 1.8 \\
\hline $49 \mathrm{~d}$ & 8.8 & 1.7 & 9.3 & 1.5 & 8.8 & 1.1 & 9.5 & 1.8 \\
\hline \multicolumn{9}{|l|}{ Live weight, $\mathrm{kg}$} \\
\hline $7 \mathrm{~d}$ & 2.64 & 0.70 & 2.48 & 0.66 & 2.74 & 0.63 & 2.50 & 0.60 \\
\hline $21 \mathrm{~d}$ & 5.54 & 1.45 & 5.21 & 1.41 & 5.59 & 1.31 & 5.06 & 1.29 \\
\hline $35 \mathrm{~d}$ & 8.43 & 2.21 & 8.06 & 1.97 & 8.39 & 2.00 & 7.69 & 2.00 \\
\hline $49 \mathrm{~d}$ & 11.23 & 3.25 & 11.37 & 2.84 & 11.12 & 2.70 & 10.71 & 2.72 \\
\hline \multicolumn{9}{|c|}{ Daily gain, g/d } \\
\hline $7-21 d$ & $205^{\mathrm{d}}$ & 75 & $194^{\mathrm{cd}}$ & 69 & $202^{\mathrm{d}}$ & 63 & $181^{\mathrm{c}}$ & 63 \\
\hline $22-35 \mathrm{~d}$ & $202^{\mathrm{a}}$ & 80 & $199^{a}$ & 68 & $199^{a}$ & 82 & $187^{\mathrm{a}}$ & 69 \\
\hline $36-49 \mathrm{~d}$ & $191^{\mathrm{c}}$ & 129 & $237^{d}$ & 115 & $188^{\mathrm{c}}$ & 112 & $214^{d}$ & 106 \\
\hline $7-49 d$ & $203^{a}$ & 69 & $211^{a}$ & 59 & $197^{a}$ & 57 & $195^{a}$ & 56 \\
\hline \multicolumn{9}{|c|}{ Creep feed intake $\mathrm{g} / \mathrm{d}$} \\
\hline $22-35 \mathrm{~d}$ & $37^{a}$ & 28 & $30^{\mathrm{a}}$ & 17 & $30^{\mathrm{a}}$ & 18 & $28^{\mathrm{a}}$ & 13 \\
\hline $36-49 \mathrm{~d}$ & $385^{a}$ & 116 & $394^{a}$ & 71 & $385^{\mathrm{a}}$ & 110 & $381^{a}$ & 77 \\
\hline \multicolumn{9}{|c|}{ Kg creep feed/kg gain } \\
\hline $36-49 \mathrm{~d}$ & $2.34^{a}$ & 1.36 & $1.84^{\mathrm{a}}$ & 0.58 & $2.12^{\mathrm{a}}$ & 0.60 & $1.89^{\mathrm{a}}$ & 0.53 \\
\hline
\end{tabular}

Means with different letters were significantly different $(\mathrm{a}, \mathrm{b} \mathrm{P}<0.05, \mathrm{c}, \mathrm{d} \mathrm{P}<0.01)$. 
ture of $2.5 \%$ DM (NÄSI and ALAVIUHKOLA 1980). In the same good condition olaquindox supplementation increased growth by $10 \%$ before weaning and by $27 \%$ after weaning (PARTANEN 1976).

ALAVIUHKOLA (1978) compared various growth promoters in the same piggery as the present study and found an improvement of growth with olaquindoxsupplementation $(44.6 \mathrm{mg} / \mathrm{kg}$ ) before weaning by $8 \%$ and by $48 \%$ after weaning. Also olaquindox-supplement has been found to increase the daily gain of weaning piglets by $33 \%$ (PFIRTER et al. 1978).

The consumption of creep feed before weaning was quite low, on average 31 $\mathrm{g} / \mathrm{d}$ in period $22-35$ days of age. Group 1 receiving a diet supplemented with sucrose alone ate $25 \%$ more feed compared to others. After weaning the differences between the groups were quite small and the intake was on average $386 \mathrm{~g} / \mathrm{d}$ in period 36-49 days. In the previous experiments at the swine research station piglets consumed considerably more feed supplemented with $2.5 \%$ polyol DM, before weaning $93 \mathrm{~g} / \mathrm{d}$ and after weaning 5-7 weeks $786 \mathrm{~g} / \mathrm{d}$. The creep feed in that trial included rather a lot of oat meal $(50 \%)$ and was thus very palatable and digestible (NÄSI and ALAVIUHKOLA 1980). Olaquindox-supplement in feed was found to increase feed consumption (PARTANEN 1976, ALAVIUHKOLA 1978 and PFIRTER et al. 1978).

A trial to study the palatability of creep feeds supplemented with two concentrations of polyol mixture $(2.5$ vs. $5.0 \% \mathrm{DM})$ was also performed at the Swine research station. The relative feed consumptions were before weaning 100-105-127 and after weaning 100-144-129 for diets with 5 \% sucrose, $2,5 \%$ polyols or $5 \%$ polyols (not published).

The satisfactory growth of piglets in the period before and after weaning depends on a high intake and digestibility of creep feed. The palatability of the diet is of great importance, and feed consumption increases when sweetening incredients, e.g. sugar, are added (LEWIS et al. 1955, ALDINGER et al. 1961). Xylitol is as sweet as sucrose, and it has a pleasant cool taste (AMINOFF 1974, EMODI 1978). LUCAS and LODGE (1961) have reported that the amount of feed required daily for a maximum growth rate of 3,4 and 5 weeks old suckling pigs is 45, 227 and $363 \mathrm{~g}$, respectively.

The groups receiving growth promoter utilised more efficient feed to daily gain, $12-27 \%$, but the differences were not statistically significant $(\mathrm{P}>0.05)$. This was attributed to the considerable variation in feed intake within the treatment. Group 3, which received polyols, utilised feed $9.5 \%$ more effectively than the control group fed on a sucrose supplemented diet. NÄSI and ALAVIUHKOLA (1980) found some improvement in feed utilisation with polyol supplementation. Olaquindoxsupplementation improved feed conversion efficiency by $20 \%$ in the Porlammi pig house, while at the Swine research station the improvement was $7 \%$ (PARTANEN 1976). PFIRTER et al. (1978) found a $6 \%$ improvement.

The health of sows and piglets was normal during the experiment. The incidence of diarrhoea is presented in Table 4. After weaning piglets fed on diet supplemented with olaquindox had fewer scours than groups without growth promoter. Group 4 fed on diet supplemented with both olaquindox and polyols had the lowest incidence of diarrhoea and also a very low mortality. Polyol inclusion in diet had no clear effect on diarrhoea. ALAVIUHKOLA (1978) reported marked decrease of diarrhoea in 
Table 4. Diarrhoea, percent of piglets at different observation times.

\begin{tabular}{lcccc}
\hline $\begin{array}{l}\text { Percentage of } \\
\text { piglets in diarrhoea }\end{array}$ & 1 Sugar & $\begin{array}{l}2 \text { Sugar }+ \\
\text { Olaquindox }\end{array}$ & 3 Polyol & $\begin{array}{c}4 \text { Polyol }+ \\
\text { Olaquindox }\end{array}$ \\
\hline $7 \mathrm{~d}$ & $5.6^{\mathrm{a}}$ & $8.4^{\mathrm{a}}$ & $5.7^{\mathrm{a}}$ & $5.4^{\mathrm{a}}$ \\
$21 \mathrm{~d}$ & $5.9^{\mathrm{cd}}$ & $3.6^{\mathrm{c}}$ & $1.6^{\mathrm{c}}$ & $10.8^{\mathrm{d}}$ \\
$35 \mathrm{~d}$ & $6.0^{\mathrm{a}}$ & $6.3^{\mathrm{a}}$ & $4.9^{\mathrm{a}}$ & $4.7^{\mathrm{a}}$ \\
$49 \mathrm{~d}$ & $9.2^{\mathrm{d}}$ & $6.5^{\mathrm{cd}}$ & $11.4^{\mathrm{d}}$ & $2.1^{\mathrm{c}}$ \\
Litters without diarrhoea & 12 & 15 & 14 & 12 \\
Litters treated & 8 & 5 & 6 & 8 \\
Diarrhoea-index $^{1}$ & 264 & 186 & 211 & 311 \\
\hline
\end{tabular}

1 Diarrhoea-index calculated by multiplying piglets in diarrhoea with score of diarrhoea. Means with different letters were significantly different $(\mathrm{a}, \mathrm{b} \quad \mathrm{P}<0.05 ; \mathrm{c}, \mathrm{d} \mathrm{P}<0.01)$

olaquindox group compared to control or other growth promoters in the same environment as the present study.

The supplementation of growth promoter in such environmental and hygienic conditions as the present experiment showed an improvement on performance of piglets. By using polyol mixture as a sweetener sucrose could be substituted. Mortality and incidence of diarrhoea decreased in groups fed on diet supplemented with polyols. Also the feed conversion efficiency was improved with polyol inclusion in the diet of piglets.

Acknowledgements. This study was made possible by the support of the Farmos Group Agricultural Division. We are indebted to Mr. O. Kähönen, Manager of Porlammi Dairy, for providing the necessary facilities for this work. Thanks are due to Mr. M. Tuomikoski and Mrs. K. Ala-Kurki for the care of the experimental animals.

\section{References}

ALAVIUHKOLA, T. 1978. Kolmen lisäaineen vertailu pikkuporsailla. Sika 8 (5): 23-24.

ALDINGER, S. M., SPEER, V. C., HAYS, V. W. \& CATRON, D. V. 1961. Effect of saccharin and sucrose on the performance of young pigs. J. Anim. Sci. 20: 249-254.

AMINOFF, C. 1974. New carbohydrate sweetener. Sugars in nutrition (Ed. H. L. SIPPLE and K. W. McNUTT). London p. 136-140.

EMODI, A. 1978. Xylitol - its properties and food applications. Food Techn. 1: 28.

L EWIS, C. J., CATron, D. V., COMBS, G. E. Jr., ASHTON, G. C. \& CUlberTSON, C. C. 1955. Sugar in pig starters. J. Anim. Sci. 14: 1103-1115.

LUGAS, I. A. M. \& LODGE, G. A. 1961. The nutrition of the young pig - a review. Techn. Commun. No 22. Rowett Institute. Aberdeen.

MÄKINEN, K., NÄSI, M. \& ALAVIUHKOLA, T. 1981. On the chemical composition of sow milk during polyol feeding. Nutr. Rep. Internat. 19. (in press).

NÄSI, M. \& ALAVIUHKOLA, T. 1980. Polyol mixture supplementation in the diet of breeding sows and piglets. J. Scient. Agric. Soc. Finl. 52: 50-58.

PALOHEIMO, L. 1969. Weender Analyse. Handb. Tierernähr. I 164-171. Hamburg.

PARTANEN, J. 1976. Bayonox porsaiden ja lihasikojen rehuseosten lisäaineena. Sika 6 (5): 11-13.

PFIRTER, H. P., HALTER, H. M., JUCKER, H. \& BICKEL, H. 1978. The influence of feeding chinoxaline derivatives on the daily gain and metabolism of piglets and growing pigs. Z. Tierphysiol. Tierernähr. Futtermittelk. 40: 191-203.

SCHEININ, A \& MÄKINEN, K. 1975. Turku sugar studies I-XXI. Acta Odont. Scand. 33. suppl. 70. STEEL, R. G. \& TORRIE, J. H. 1960. Principles and procedures of statistics. 481 p. New York.

Ms received February 9, 1981. 


\title{
Polyoliseos porsasrehun makeutus- ja/tai lisäaineena
}

\section{Matti Näsi}

Helsingin yliopisto, kotieläintieteen laitos, 00710 Helsinki 71

\section{Timo Alaviuhkola}

\author{
Sikatalouskoeasema, 05840 Hyvinkää 4
}

Tutkimuksessa selvitettiin polyolilisäyksen (sokerialkoholiseos) vaikutusta porsaiden kasvuun, rehunkulutukseen, rehuhyötysuhteeseen sekä ripulin esiintymiseen. Kokeessa oli neljä ryhmāä, joissa kussakin 20 pahnuetta. $2 \times 2$ faktorikokeessa ryhmät saivat rehuseosta, jossa oli (1) $4 \%$ sakkaroosia, (2) $4 \%$ sakkaroosia +50 mg olaquindox-lisảainetta/kg rehua, (3) $8 \%$ polyoliseosta (4\% ka) ja (4) $8 \%$ polyoli seosta +50 mg olaquindoxlisäainetta/ $\mathrm{kg}$ rehua. Porsasrehua annettiin viikon iästä. Vieroituksen jälkeen $5-7$ ikäviikoilla porsasrehu oli yksinomaisena rehuna. Pahnueiden keskimääräinen koko oli 9.9 porsasta. Porsaskuolleisuus oli $11.2 \%, 8.4 \%, 8.8$ \% ja $6.4 \%$ ryhmissä 1, 2, 3 ja 4, 1 ja 7 viikon välillä. Vieroituksen jälkeen olaquindox-lisäaine paransi porsaiden lisäkasvua $13.8 \%$ ja $24 \%$ vertailuryhmään nähden. Rehunsyönti ennen vieroitusta oli vähäistä, keskimäärin 31 $\mathrm{g}$ päivässä. Rehunkulutuksessa eri ryhmien välillä ei ollut eroja vieroituksen jälkeen. Suhteelliset rehuhyötysuhteet olivat 100, 79, 90 ja 81 ryhmissä 1,2, 3 ja 4. Rehun lisäaine vähensi ripulin esiintymistä porsailla vieroituksen jälkeen. Polyoliseoksella voitiin korvata sokeri makeutusaineena ja porsaskuolleisuus laski polyolilisän vaikutuksesta. Kãyttämällä rehun lisảainetta saatiin näissä olosuhteissa parempia tuloksia porsaiden kasvusta ja rehun hyväksikāytöstä. 